\title{
Automated estimation of urinary calcium using the Eppendorf flame photometer
}

\author{
A. M. BOLD \\ From the Department of Chemical Pathology, St. Thomas' Hospital Medical School, London
}

SYNOPSIS A method is described for estimating urine calcium on a mechanized Eppendorf flame photometer with twin channels at a rate of 60 per hour. Sodium is estimated simultaneously so that a correction can be made for the small sodium error. Errors due to potassium and phosphate are minimized by adding these ions to the standards and to the diluting fluid. Results agree well with those obtained by Trinder's naphthal-hydroxamic acid precipitation method.

High-temperature flame photometry provides a simple and rapid method for estimating calcium in urine, but this method is subject to interference, especially by sodium. We have attempted to reduce these difficulties by using a mechanized Eppendorf flame photometer with a second channel and a diluting fluid containing potassium and phosphate which minimizes interference from these ions. The urine sodium concentration can be measured simultaneously and a correction made.

\section{METHOD}

URINE COLLECTION Urine is collected for 24 hours in bottles containing $10 \mathrm{ml}$. concentrated hydrochloric acid (or more safely, $100 \mathrm{ml}$. of approximately normal hydrochloric acid). The total volume of the urine is made up with distilled water to at least $1,500 \mathrm{ml}$. Very few urine specimens then need further dilution.

REAGENTS Analar grade reagents are used.

Stock standard calcium solution, $100 \mathrm{mg} .100 \mathrm{ml}$. Calcium carbonate $2.50 \mathrm{~g}$., previously dried at $110^{\circ} \mathrm{C}$. for two hours, is dissolved in $50 \mathrm{ml}$. N.hydrochloric acid and the volume made up to 1 litre with distilled water.

Stock standard sodium chloride solution, $1,000 \mathrm{mEq} . / \mathrm{l}$. Of previously dried sodium chloride, $58.45 \mathrm{~g}$., is dissolved in distilled water and the volume made up to 1 litre.

Received for publication 4 July 1966.
Stock potassium chloride solution, $100 \mathrm{mEq} . / \mathrm{l}$. Of dried potassium chloride, $74.55 \mathrm{~g}$. is dissolved in distilled water and the volume made up to 1 litre.

Stock ammonium phosphate $\left(\mathrm{NH}_{4}\right)_{2} \mathrm{HPO}_{4}, 10 \mathrm{~g}$. phosphorus/l. Ammonium phosphate, $42.6 \mathrm{~g}$., is dissolved in distilled water and the volume made up to 1 litre.

WORKING CALCIUM STANDARDS These are made up from the stock solutions as tabulated below. Each calcium standard solution thus has a concentration of sodium $100 \mathrm{mEq}$./1., of potassium $75 \mathrm{mEq}$./1., and of phosphorus $600 \mathrm{mg} . / 1$.

WORKING SODIUM STANDARD SOLUTIONS These are made up to contain sodium at a concentration of 50,100 and $150 \mathrm{mEq} . / 1$.

DILUTING FLUID This is made up by taking $25 \mathrm{ml}$. of stock potassium chloride, $10 \mathrm{ml}$. of stock ammonium phosphate, $10 \mathrm{ml}$. of concentrated hydrochloric acid, and 15 drops of Tween 20 and adding distilled water to make the volume 5 litres.

\section{APPARATUS}

An Eppendorf flame photometer was used, mechanized as previously described (Bold, Hurst, and McSwiney, 1965) and incorporating three solar cells to provide a second channel (Hurst and Bold, 1966).

\begin{tabular}{|c|c|c|c|c|c|c|}
\hline $\begin{array}{l}\text { Calcium } \\
\text { Concentration } \\
(\mathrm{mg} . / 100 \mathrm{ml} .)\end{array}$ & $\begin{array}{l}\text { Stock Calcium } \\
\text { Solution } \\
(\mathrm{ml} .)\end{array}$ & $\begin{array}{l}\text { Stock Sodium } \\
\text { Solution } \\
(m l .)\end{array}$ & $\begin{array}{l}\text { Stock Potassium } \\
\text { Chloride Solution } \\
(\mathrm{ml} .)\end{array}$ & $\begin{array}{l}\text { Stock Ammonium } \\
\text { Phosphate Solution } \\
(\mathrm{ml} .)\end{array}$ & $\begin{array}{l}\text { Concentrated } \\
\text { Hydrochloric Acid } \\
(\mathrm{ml} .)\end{array}$ & $\begin{array}{l}\text { Distilled } \\
\text { Water } \\
(\mathrm{ml} .)\end{array}$ \\
\hline $\begin{array}{r}0 \\
10 \\
20 \\
30 \\
40\end{array}$ & $\begin{array}{r}0 \\
10 \\
20 \\
30 \\
40\end{array}$ & $\begin{array}{l}10 \\
10 \\
10 \\
10 \\
10\end{array}$ & $\begin{array}{l}7 \cdot 5 \\
7 \cdot 5 \\
7 \cdot 5 \\
7 \cdot 5 \\
7 \cdot 5\end{array}$ & $\begin{array}{l}6 \\
6 \\
6 \\
6 \\
6\end{array}$ & $\begin{array}{l}1 \\
1 \\
1 \\
1 \\
1\end{array}$ & $\begin{array}{l}\rightarrow 100 \\
\rightarrow 100 \\
\rightarrow 100 \\
\rightarrow 100 \\
\rightarrow 100\end{array}$ \\
\hline
\end{tabular}


Both channels are used with the appropriate filters for estimating calcium and sodium; calcium is estimated on the normal flame photometer channel, sodium on the solar cell channel. An air-acetylene flame is used as previously described for estimating calcium in plasma. Specimens are mechanically sampled by an AutoAnalyzer mark I sampler at 60 per hour and automatically diluted (approximately 1 in 50 ) in the special diluting fluid. (The same manifold may be used for estimating plasma, but it is most important that it is thoroughly washed out.)

\section{PROCEDURE}

The apparatus is warmed up for a minimum of 30 minutes by continuously sampling a solution containing calcium $40 \mathrm{mg} . / 100 \mathrm{ml}$. and sodium $100 \mathrm{mEq}$./l. The deflection on the recorder measuring calcium is adjusted to approximately $90 \%$, the deflection on the recorder measuring sodium to $50 \%$.

When the deflections on the recorders are stable, standard solutions of sodium 50,100 , and $150 \mathrm{mEq} . / 1$. are sampled. These are followed by calcium standard solutions, 0 to $40 \mathrm{mg}$. $/ 100 \mathrm{ml}$. Urine specimens are then sampled in batches of five, followed by a reference calcium standard of $20 \mathrm{mg} . / 100 \mathrm{ml}$. As the standards contain $100 \mathrm{mEq}$. sodium/l., this is used to check stability on both channels. If the apparatus is clean and thoroughly warmed up, drift should not exceed $5 \%$ in an hour.

Changes in the reference standard solutions are used to correct the estimation of each batch of urinespecimens. (The problem of correcting for drift in auto-analysis is discussed by Thiers and Oglesby, 1964.)

\section{EXPERIMENTAL}

STANDARD CURVES The standard curve for calcium is linear up to $40 \mathrm{mg} . / 100 \mathrm{ml}$. (Fig. 1). Higher concentrations of calcium have not been tested, since a calcium concentration in urine greater than $40 \mathrm{mg} . / 100 \mathrm{ml}$. is uncommon when 24-hour urine collections are made up to $1,500 \mathrm{ml}$. Figure 1 also shows the extent to which a sample with a high calcium concentration can contaminate the following sample with a low calcium concentration. An error up to $1 \mathrm{mg} . / 100 \mathrm{ml}$. can result. For this reason, occasional samples may need to be run again.

INTERFERENCE Pure solutions of sodium chloride give significant readings as apparent calcium. The effect is virtually linear up to a sodium concentration of 1,000 $\mathrm{mEq} . / \mathrm{l}$, a mean value for apparent calcium of $0.11 \mathrm{mg}$./ $100 \mathrm{ml}$. being obtained per $10 \mathrm{mEq} . / \mathrm{l}$. sodium. This appears to be due to a slight optical leak by the interference filter. The magnitude of the error was not affected by the presence of calcium and could not be reduced by adding sodium to the diluting fluid. Table I summarizes the results obtained in testing sodium interference.

The effect of adding potassium chloride and ammonium phosphate to pooled urine and to pure solutions of calcium chloride was measured. The apparent calcium concentration was increased. This effect was not observed when ammonium chloride was added, and the error was

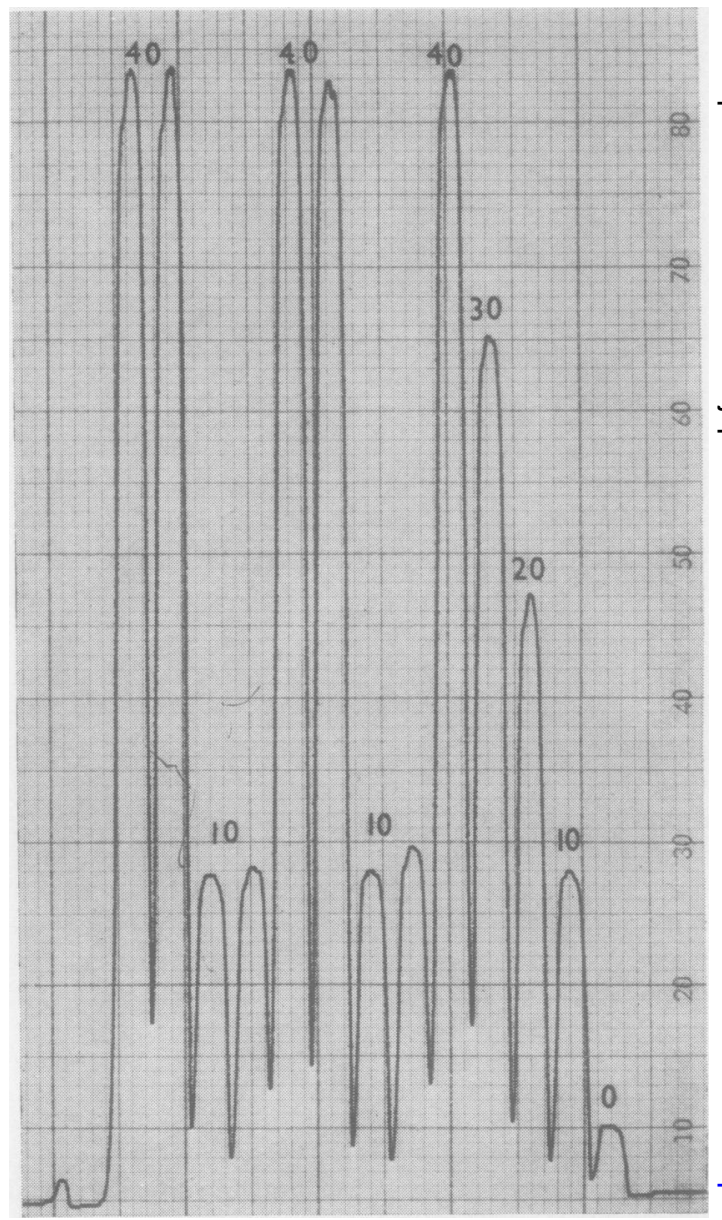

FIG. 1. A photograph of the standard curve for calcium, 0 to $40 \mathrm{mg}$./100 ml. The extent of contamination occurring when solutions containing 10 and $40 \mathrm{mg} . / 100 \mathrm{ml}$. are alternated is shown.

considered to be due to potassium and phosphate ions. $\bigcirc$ Unlike sodium, the error per unit of potassium or phosphate decreased at high concentrations of these ions. By adding potassium and phosphate to the diluting fluid, the measured increase in calcium concentration was reduced $N$ to $+0.03 \mathrm{mg}$. $/ 100 \mathrm{ml}$. for every $10 \mathrm{mEq}$. of potassium/l. and to $+0.016 \mathrm{mg} . / 100 \mathrm{ml}$. for every $100 \mathrm{mg}$. of phosphorus/l. The error was not significantly different at $\mathbb{\omega}^{N}$ calcium concentrations of 5,10 , and $20 \mathrm{mg} . / 100 \mathrm{ml}$.

Magnesium sulphate, at a concentration of $200 \mathrm{mg} . / 100$ $\mathrm{ml}$., ammonium chloride at $1 \mathrm{~g} . / 100 \mathrm{ml}$., glucose at

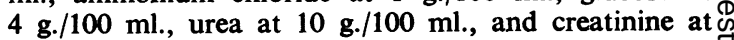
$400 \mathrm{mg} . / 100 \mathrm{ml}$. had no detectable effect on the measured calcium concentration, either in pure solutions of calcium chloride or in a pooled specimen of urine.

RECOVERY The recovery of calcium added to pooled $\stackrel{\mathscr{D}}{\mathscr{D}}$ urine from normal subjects and in-patients was measured. 
TABLE I

EFFECT OF SODIUM CONCENTRATION ON MEASURED CALCIUM CONCENTRATION

\begin{tabular}{lll}
$\begin{array}{l}\text { Sodium } \\
\text { Concentration }\end{array}$ & $\begin{array}{l}\text { Apparent Calcium } \\
\text { Concentration }\end{array}$ & $\begin{array}{l}\text { Apparent Calcium } \\
\text { Concentration per }\end{array}$ \\
& $(m \mathrm{mE} . / \mathrm{l})$. & $\begin{array}{l}10 \mathrm{mEq} . / \mathrm{l} . \text { Sodium } \\
(\mathrm{mg} . / 100 \mathrm{ml} .)\end{array}$ \\
\hline
\end{tabular}

(a)

$\begin{array}{rrr}100 & 1 \cdot 2 & 0 \cdot 12 \\ 200 & 2 \cdot 2 & 0 \cdot 11 \\ 500 & 5 \cdot 3 & 0 \cdot 11 \\ 1,000 & 10 \cdot 1 & 0 \cdot 10\end{array}$

(b)

$\begin{array}{lll}100 & 10 \cdot 0 & - \\ 120 & 10 \cdot 28 & +0 \cdot 14 \\ 140 & 10 \cdot 4 & +0 \cdot 10 \\ 160 & 10 \cdot 58 & +0 \cdot 10 \\ 180 & 10.90 & +0 \cdot 11 \\ 200 & 11.08 & +0 \cdot 11 \\ 250 & 11.43 & +0 \cdot 10\end{array}$

(a) Pure solutions of sodium chloride read as apparent calcium against pure calcium standard solutions.

(b) Solutions, all containing calcium $10 \mathrm{mg} . \%$, with varying sodium concentration, read against calcium standard solutions containing sodium $100 \mathrm{mEq} . / 1$.

A similar effect of sodium was noted when sodium was added to solutions containing calcium 5 and $20 \mathrm{mg} \%$, and when added to urine.

The calcium added was equivalent to raising the urine concentration by from 4 to $20 \mathrm{mg}$./100 ml. Two separate recovery experiments were performed. The results are shown in Table II. The mean recovery of added calcium was $99.8 \%$.

\section{TABLE II}

THE RECOVERY OF CALCIUM ADDED TO TWO SAMPLES OF POOLED URINE (a) AND (b)

$\begin{array}{llll}\begin{array}{l}\text { Initial Calcium } \\ \text { Concentration }\end{array} & \begin{array}{l}\text { Calcium Concen- } \\ \text { tration Expected }\end{array} & \begin{array}{l}\text { Concentration } \\ \text { (mg. } / 100 \mathrm{ml} .)\end{array} & \begin{array}{l}\text { Percentage } \\ \text { Recovery }\end{array} \\ & \begin{array}{l}\text { Added Calcium } \\ (\mathrm{mg} . / 100 \mathrm{ml} .)\end{array} & \begin{array}{l}\text { Found } \\ (\mathrm{mg} . / 100 \mathrm{ml} .)\end{array} & \\ & & \end{array}$

Sample $a$ $10 \cdot 75$

$10 \cdot 75$

10.75

10.75

$14 \cdot 75$
$18 \cdot 75$
$22 \cdot 75$
$30 \cdot 75$

14.65

18.65

22.65

99

$99 \cdot 5$

$99 \cdot 5$

98.5

Sample $b$

$\begin{array}{llll}11.9 & 15.9 & 16.1 & 101 \\ 11.9 & 19.9 & 19.9 & 100 \\ 11.9 & 23.9 & 24.2 & 101 \\ 11.9 & 31.9 & 32.0 & 100\end{array}$

COMPARISON WITH TRINDER's METHOD Fifty specimens of urine from patients and hospital staff were estimated in duplicate by the method described above. The results were compared with duplicate estimations obtained by the naphthal-hydroxamic acid precipitation method described by Trinder (1960). This method was modified by using $0.2 \mathrm{ml}$. urine in volumes of all reagents double those in the original method. This permitted more satisfactory estimation of calcium in high concentration. Also the 24-hour volume of some of the urine specimens was less than the 2 litres suggested in that method.
The calcium concentration of the 50 urine specimens tested varied from 1.4 to $40.0 \mathrm{mg} . / 100 \mathrm{ml}$. Their sodium concentrations varied from 8 to $159 \mathrm{mEq}$./1. In 36 out of 50 comparisons the calcium estimation by flame photometry was the lower. Overall, the mean percentage difference was $-1.6 \% \pm 2.6 \%$ (standard deviation).

PRECISION The precision of these two methods was calculated from the differences between duplicate estimations of 50 urines (Henry, 1964). The coefficient of variation of the automated flame photometric method was $1 \cdot 2 \%$; that for Trinder's method was $2 \cdot 2 \%$.

\section{DISCUSSION}

Using an interference filter to measure the calcium oxide band at $620 \mathrm{~m} \mu$, the main problem in the flame photometric estimation of urinary calcium is interference by sodium. The error may be reduced by including sodium in the standard calcium solutions, though no means has been found of eliminating the error entirely. On our flame phótometer, over the range of sodium concentration 0 to $200 \mathrm{mEq}$./1. this error does not exceed $1 \mathrm{mg} . / 100 \mathrm{ml}$. The maximum error, therefore, is unlikely to exceed 10 to $20 \mathrm{mg}$. of calcium a day, an error unimportant for routine clinical purposes. However, if greater accuracy is required, as for calcium balance experiments, especially when the urine calcium concentration is low, the sodium concentration of the urine can be estimated, and the observed calcium concentration corrected. By using a flame photometer to estimate sodium and calcium simultaneously, little extra time is needed to make this correction.

The interference by potassium and phosphate can be reduced by using high concentrations of these ions in the diluting fluid, and by adding them to the calcium standard solutions in concentrations which are approximately average for urine. Under these conditions, the error likely to be caused by potassium and phosphate is small. All other substances tested have been found not to interfere in the estimation.

The accuracy of the method in practice was confirmed by comparisons with Trinder's method. The measure of agreement between two methods employing totally different principles for estimating calcium suggests that both methods are sufficiently accurate for the estimation of calcium in urine.

In clinical work, the estimation of urinary calcium is rarely required urgently, so that it is very suitable for batch analysis by an automated technique. The method described here has the advantages of speed and precision; pipetting, necessary in Trinder's method, is avoided; furthermore, if required, the flame photometer may be used for manual estima- 
tions in the normal way simply by disconnecting the tubing to the flame photometer atomizer and substituting the normal pick-up tubing.

It is a pleasure to thank Dr. R. R. McSwiney and Dr. B. W. Meade for helpful advice and criticism, and Dr. M. E. A. Powell, who took the photograph.
REFERENCES

Bold, A. M., Hurst, R. J., and McSwiney, R. R. (1965). J. clin. Path., 18, 240.

Henry, R. J. (1964). Clinical Chemistry, Principles and Techniques, p. 125. Hoeber Medical Division, Harper and Row, New York.

Hurst, R. J., and Bold, A. M. (1966). J. clin. Path., 19, 622.

Thiers, R. E., and Oglesby, K. M. (1964). Clin. Chem., 10, 246.

Trinder, P. (1960). Analyst, 85, 889. 622.

\section{Reports and Bulletins prepared by the Association of Clinical Biochemists}

The following reports and bulletins are published by the Association of Clinical Biochemists. They may be obtainedo from Mr. J. T. Ireland, Biochemistry Laboratory, Alder Hey Children's Hospital, Liverpool, 12. The prices include స్ postage, but airmail will be charged extra.

\section{SCIENTIFIC REPORTS}

1 Colorimeters with Flow Through Cells. A Critical Assessment of 4 Instruments. 1965. P. M. G. BROUGHTON and C. RILEY. $13 \mathrm{~s} 6 \mathrm{~d}$.

2 Colorimeters: A critical assessment of 5 commercial instruments. 1966. P. M. G. BROUGHTON, C. RILEY, J. G. H. COOK, P. G. SANDERS and H. BRAUNSBERG. 15 s.

\section{TECHNICAL BULLETINS}

2 A Report on the Enzyme Questionnaire Circulated by the Scientific Committee. December 1964. A. H. GOWENLOCK. 1s.

3 Non-recording Spectrophotometers for the Visible and Ultraviolet Ranges. A comparative table of instruments available in Great Britain. May 1965. A. H.
GOWENLOCK, P. C. NICHOLAS, and J. H. WILKINSON. $\stackrel{\circ}{\lrcorner}$ 1s. 6 d.

4 Control Solutions for Clinical Biochemistry. June 1965. P. M. G. BROUGHTON and A. H. GOWENLOCK.马 1s. $6 \mathrm{~d}$.

5 Recording Spectrophotometers. A comparative list of low-priced instruments readily available in Britain. July 1965 . P. SEWELL. 2s. 6 d.

6 A Guide to Automatic Pipettes. A list of more than 100 instruments compiled from manufacturers' literature. August 1965. P. M. G. BROUGHTON. 5s.

7 Variability Between AutoAnalyzer Modules. August 1965. B. E. NORTHAM. 1s. 6 d.

8 Flame Photometers. A comparative list of 15 instru-? ments readily available in Britain. June 1966 范 C. RILEY. 4s. 